Article

\title{
Assessment of Fish Quality Based on the Content of Heavy Metals
}

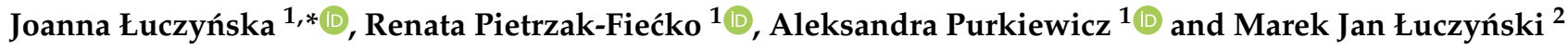 \\ 1 Department of Commodity and Food Analysis, Faculty of Food Science, University of Warmia and Mazury in \\ Olsztyn, 10-726 Olsztyn, Poland; renap@uwm.edu.pl (R.P.-F.); aleksandra.purkiewicz@uwm.edu.pl (A.P.) \\ 2 Department of Ichthyology, Hydrobiology and Ecology of Waters, The Stanisław Sakowicz Inland Fisheries \\ Institute in Olsztyn, 10-719 Olsztyn, Poland; mj.luczynski@infish.com.pl \\ * Correspondence: jlucz@uwm.edu.pl; Tel.: +48-89-523-41-65
}

Citation: Łuczyńska, J.;

Pietrzak-Fiećko, R.; Purkiewicz, A.; Łuczyński, M.J. Assessment of Fish Quality Based on the Content of Heavy Metals. Int. J. Environ. Res. Public Health 2022, 19, 2307. https:/ / doi.org/10.3390/ijerph19042307

Academic Editor: José

Ángel Fernández

Received: 20 December 2021

Accepted: 15 February 2022

Published: 17 February 2022

Publisher's Note: MDPI stays neutral with regard to jurisdictional claims in published maps and institutional affiliations.

Copyright: (C) 2022 by the authors. Licensee MDPI, Basel, Switzerland. This article is an open access article distributed under the terms and conditions of the Creative Commons Attribution (CC BY) license (https:// creativecommons.org/licenses/by/ $4.0 /)$.
Abstract: The aim of this study was to estimate the fish quality in terms of the $\mathrm{Cu}, \mathrm{Fe}, \mathrm{Mn}$ and $\mathrm{Zn}$ contents. The research material was the muscle tissue of the fish crucian carp (Carassius carassius Linnaeus, 1758), flounder (Platichthys flesus Linnaeus, 1758), Gilthead seabream (Sparus aurata Linnaeus, 1758), mackerel (Scomber scombrus Linnaeus, 1758), Blue grenadier (Macruronus novaezelandiae Hector, 1871), rainbow trout (Oncorhynchus mykiss Walbaum, 1792), tench (Tinca tinca Linnaeus, 1758), tilapia (Oreochromis niloticus Linnaeus, 1758), Walleye pollock (Gadus chalcogrammus Pallas, 1814) and perch (Perca fluviatilis Linnaeus, 1758.). Heavy metals were determined with the atomic absorption spectrometry method (AAS). Significantly high concentrations of zinc (19.52 mg/ $\mathrm{kg}$ wet weight), copper $(0.77 \mathrm{mg} / \mathrm{kg})$ and iron $(6.95 \mathrm{mg} / \mathrm{kg})$ were found in the muscles of crucian carp $(p<0.05)$ compared to the other fish studied, whereas Walleye pollock had a higher content of manganese $(0.266 \mathrm{mg} / \mathrm{kg})(p<0.05)$. All studied fish species do not pose a threat to humans from these four metals. This was indicated by quality indexes (THQ and HI) whose values were below one. The values of these metals also did not exceed the maximum allowable concentrations established by the FAO (1983), but monitoring both the aquatic environment and the fish living there is necessary, for example, for the time-changing abiotic and biotic factors that can cause an increase in metals in the organs of fish.

Keywords: heavy metals; marine fish; freshwater fish; Target Hazard Quotient; the combined risk; Hazardous Index

\section{Introduction}

Fish are an important component of the healthy human diet because of their high nutritional quality. The recommended fish consumption is at least two times a week (quantities of approx. $300 \mathrm{~g}$ ). The mean daily fish consumption in 2019 in Poland accounted for $12.7 \mathrm{~kg}$ per person ( $244 \mathrm{~g}$ /week), and in 2020, it was $13.33 \mathrm{~kg}$ per person ( $256 \mathrm{~g} / \mathrm{week})$, while the average person, living in Europe, consumed $24.4 \mathrm{~kg}$ of fish or seafood per year [1,2]. Sea fish account for the greatest share in consumption (app. 78\%) in Poland. The shares of freshwater fish and seafood are much lower (app. 18\% and 4\%, respectively) [3].

Fish is one of the main sources of easily digestible protein rich in essential amino acids, fats, macro- and trace elements, and fat-soluble vitamins. Fish is a food rich in valuable long chain polyunsaturated omega-3 fatty acids $[4,5]$.

The appropriate quantities of n-3 PUFA, such as eicosapentaenoic (EPA, C20:5 n-3), docosahexaenoic (DHA, C22:6 n-3) and ocosapentaenoic acid (DPA, C22:5 n-3), prevent or reduce the risk of cancer, cardiovascular diseases and neurological disorders [6-9]. Scientific studies have confirmed that PUFA play an important role in the growth of the fetus and the development of cognitive functions in children [10]. 
However, fish also have the ability to accumulate trace elements, heavy metals, pesticide residues and persistent organic pollutants in their tissues, including polychlorinated biphenyls (PCBs) [11-13]. The organic pollutants, next to heavy metals, can be harmful to the aquatic ecosystem and humans by the consumption of fish. For example, Georgieva et al. [14] studied the short-term effects of different concentrations of two pesticides (chlorpyrifos (CPF) and cypermethrin (CYP)) in common carp (Cyprinus carpio Linnaeus, 1758) under laboratory conditions. The authors, based on the results obtained in the experiment, concluded that, to avoid any risk, these pesticides should be used with caution, especially near water reservoirs. Organic substances like pesticides are harmful to fish, which can be said to reduce the health properties of fish meat [15]. According to Betts et al. [16], the practice of using pesticides is a threat not only for inland fisheries, but it is a global problem, because as a consequence, it can be harmful for human health.

Fish accumulate substantial amounts of metals in their tissues, especially in the muscles. Many factors influence the metal contents in fish tissues, such as environmental quality, season, fish species, stage and age of maturity [12]. According to Nyeste et al. [17], the specific diet of age groups of a given species and the bioindicator capacities of different age groups are also important. Fish samples are considered as one of the most indicative factors, in freshwater systems, for the estimation of the trace metal pollution potential.

Microelements such as zinc $(\mathrm{Zn})$, iron $(\mathrm{Fe})$, manganese $(\mathrm{Mn})$ and copper $(\mathrm{Cu})$, also called trace elements, are present in the human body in amounts less than $0.01 \%$, and the daily requirement is usually less than $100 \mathrm{mg} /$ day [18]. These elements, present in physiological concentrations, are necessary for the proper functioning of living organisms. They are components of many enzymes and take part in many life processes. They are involved in the synthesis of hormones and other substances, helping to regulate the growth, development and functioning of the reproductive and immune systems [19-22]. Trace elements can cause harmful health effects when they accumulate in organisms in concentrations above those required for metabolic functions. A high consumption of copper, zinc and lead has been linked to Alzheimer's disease. Zinc and iron have been linked to Parkinson's disease, and cadmium can cause, among others, kidney dysfunction, osteomalacia and reproductive deficiencies $[23,24]$.

The levels of the trace elements in fish are important, because fish is an important source of food for the general human population [25].

The aims of this study were: determining the copper, iron manganese and zinc contents in ten selected species of fish obtained from the Polish market; conducting a health risk assessment using the Target Hazard Quotient (THQ), the combined risk (TTHQ) and Hazardous Index (HI) and the coverage of the demand (\%) for $\mathrm{Cu}, \mathrm{Fe}, \mathrm{Mn}$ and $\mathrm{Zn}$ after consuming an average portion of fish $(150 \mathrm{~g})$.

\section{Materials and Methods}

\subsection{Sampling and Sample Preparation}

The fish samples: crucian carp (Carassius carassius Linnaeus, 1758$)(n=6)$, flounder (Platichthys flesus Linnaeus, 1758) $(n=6)$, Gilthead seabream (Sparus aurata Linnaeus, 1758) $(n=6)$, mackerel (Scomber scombrus Linnaeus, 1758) $(n=6)$, Blue grenadier (Macruronus novaezelandiae Hector, 1871) $(n=9)$, rainbow trout (Oncorhynchus mykiss Walbaum, 1792) $(n=12)$, tench (Tinca tinca Linnaeus, 1758) $(n=6)$, tilapia (Oreochromis niloticus Linnaeus, 1758) $(n=5)$, Walleye pollock (Gadus chalcogrammus Pallas, 1814) $(n=6)$ and perch (Perca fluviatilis Linnaeus, 1758) $(n=10)$ were bought from the local market.

Among the studied fish (Table 1), there were also those from Baltic catches, i.e., Polish Catch Area (flounder); aquaculture Polish inland waterways (rainbow trout); harvested by fishermen from our lakes (perch, tench and crucian carp); fish from ocean catches (Walleye pollock and Blue grenadier-Pacific Ocean and mackerel-Atlantic Ocean) or sea (Gilthead seabream-Mediterranean Sea) and fish imported from China (tilapia). 
Table 1. Differences $(x \pm S D)$ in the contents of heavy metals $(\mathrm{mg} / \mathrm{kg}$ wet weight $)$ in the same organs of fish.

\begin{tabular}{|c|c|c|c|c|c|}
\hline Species & & $\mathrm{Cu}$ & $\mathrm{Fe}$ & Mn & Zn \\
\hline Crucian carp & $\mathrm{x}$ & $0.77 \mathrm{a}$ & $6.95 \mathrm{a}$ & $0.12 \mathrm{~b}$ & $19.52 \mathrm{a}$ \\
\hline (Carassius carassius L.) & SD & 0.06 & 1.19 & 0.02 & 5.14 \\
\hline Flounder & $\mathrm{x}$ & $0.26 \mathrm{~b}$ & $1.02 \mathrm{c}$ & $0.03 \mathrm{c}$ & $4.09 \mathrm{~b}$ \\
\hline (Platichthys flesus L.) & SD & 0.05 & 0.25 & 0.01 & 0.35 \\
\hline Gilthead seabream & $x$ & $0.24 \mathrm{~b}$ & $0.78 \mathrm{~d}$ & $0.03 \mathrm{c}$ & $4.01 \mathrm{~b}$ \\
\hline (Sparus aurata L.) & SD & 0.07 & 0.25 & 0.01 & 0.38 \\
\hline Mackerel & $x$ & $0.35 \mathrm{~b}$ & $1.83 \mathrm{~b}$ & $0.02 \mathrm{c}$ & $3.03 \mathrm{~b}$ \\
\hline (Scomber scombrus L.) & SD & 0.10 & 0.50 & 0.01 & 0.28 \\
\hline Blue grenadier & $\mathrm{x}$ & $0.36 \mathrm{~b}$ & $1.16 \mathrm{c}$ & $0.03 c$ & $2.98 \mathrm{~b}$ \\
\hline (Macruronus novaezelandiae Hector) & SD & 0.08 & 0.19 & 0.00 & 0.15 \\
\hline Perch & $\mathrm{x}$ & $0.23 \mathrm{~b}$ & $1.55 \mathrm{~b}$ & $0.08 \mathrm{c}$ & $3.07 \mathrm{~b}$ \\
\hline (Perca fluviatilis L.) & SD & 0.02 & 0.01 & 0.01 & 0.18 \\
\hline Rainbow trout & $\mathrm{x}$ & $0.27 \mathrm{~b}$ & $1.77 \mathrm{~b}$ & $0.07 \mathrm{c}$ & $4.93 \mathrm{~b}$ \\
\hline (Oncorhynchus mykiss Walb.) & SD & 0.04 & 0.27 & 0.01 & 0.69 \\
\hline Tench & $\mathrm{x}$ & $0.23 \mathrm{~b}$ & $1.65 \mathrm{~b}$ & $0.09 \mathrm{c}$ & $3.33 \mathrm{~b}$ \\
\hline (Tinca tinca L.) & SD & 0.05 & 0.41 & 0.02 & 0.43 \\
\hline Tilapia & $\mathrm{x}$ & $0.16 \mathrm{c}$ & $1.06 \mathrm{c}$ & $0.05 \mathrm{c}$ & $3.05 \mathrm{~b}$ \\
\hline (Oreochromis niloticus L.) & SD & 0.03 & 0.24 & 0.02 & 0.32 \\
\hline Walleye pollock & $\mathrm{x}$ & $0.29 \mathrm{c}$ & $1.11 \mathrm{c}$ & $0.27 \mathrm{a}$ & $3.27 \mathrm{~b}$ \\
\hline (Gadus chalcogrammus Pallas) & SD & 0.04 & 0.22 & 0.07 & 0.30 \\
\hline
\end{tabular}

$\mathrm{x}$ - mean; SD—standard deviation; $\mathrm{a}, \mathrm{b}, \mathrm{c}$ and $\mathrm{d}$ - significant differences between the same organs of the different species $(p<0.05)$. The same letter indicates the absence of significant differences $(p>0.05)$.

Whole and gutted fish were transported to the laboratory, and then, the muscle tissue was collected from the dorsal part. The samples were closed in plastic bags and were kept at $-30{ }^{\circ} \mathrm{C}$ until the analysis. After defrosting the individual parts, they were subjected to grinding and, then, thorough mixing prior to analysis. Frozen fish fillets were thawed and ground just before weighing. A plastic knife and fork were used to prepare the fish. These activities were performed on plastic, disposable plates. Samples were prepared in two parallel replications. After grinding, the samples were weighed and placed in quartz dishes. Reagent tests were performed in parallel.

\subsection{Element Analysis (Copper, Iron, Manganese and Zinc)}

In order to mineralize the samples of whole and gutted fish muscles and frozen fillets, they were dried at $105^{\circ} \mathrm{C}$ and then carbonized on plates and incinerated in electric furnaces (Nabertherm $\mathrm{GmbH}$, Lilienthal, Germany) at $480{ }^{\circ} \mathrm{C}$ to obtain the color of ash. The obtained ash was diluted in $5 \mathrm{~cm}^{3}$ of 1-M nitric acid (Suprapur, Merck, Darmstadt, Germany), then quantitatively transferred with deionized water (Merck-Millipore Elix Advantage 3, Merck-Millipore, Burlington, MA, USA) into $25 \mathrm{~cm}^{3}$ flasks. The contents of copper, iron, manganese and zinc were measured with flame atomic absorption spectrometry (iCE 3000 Series AAS, Thermo Scientific, Waltham, MA, USA) [26]. Measurements were conducted at the wavelength $324.8 \mathrm{~nm}$ for copper, $248.3 \mathrm{~nm}$ for iron, $279.5 \mathrm{~nm}$ for manganese and $213.9 \mathrm{~nm}$ for zinc, respectively. Four blanks and four standards were analyzed with each batch of samples. The calibration curves were developed using four solution standards $(1000 \mu \mathrm{g} / \mathrm{L})$ with 0.1-M $\mathrm{HNO}_{3}$ supplied by J.T. Baker ${ }^{\circledR}$ (J.T. Baker Chemicals Company, Deventer, The Netherlands). The calibration curves were linear within the range of heavy metal contents (regression coefficients $\mathrm{R}^{2} \geq 0.999$ ). The detection limits (LOD) were $0.05 \mathrm{mg} / \mathrm{kg}$ for $\mathrm{Cu}, 0.5 \mathrm{mg} / \mathrm{kg}$ for Fe, $0.05 \mathrm{mg} / \mathrm{kg}$ for Mn and $0.1 \mathrm{mg} / \mathrm{kg}$ for $\mathrm{Zn}$. The sensitivity was as follows: $0.05 \mathrm{mg} / \mathrm{dm}^{3}, 0.02 \mathrm{mg} / \mathrm{dm}^{3}, 0.02 \mathrm{mg} / \mathrm{dm}^{3}$ and $0.05 \mathrm{mg} / \mathrm{dm}^{3}$, respectively. The lyophilized certified material (BCR CRM 422 (muscles of cod Gadus morhua (L.)) was also analyzed with a known elemental content. The recovery rates were: $103.0 \% \mathrm{Cu}, 96 \% \mathrm{Fe}, 103 \% \mathrm{Mn}$ and $105.0 \% \mathrm{Zn}$, respectively. 


\subsection{Noncarcinogenic Target Hazard Quotient (THQ)}

When the THQ $<1$, there are health benefits from fish consumption $[27,28]$, whereas a THQ $>1$ suggests a high probability of an adverse risk to human health.

$$
\mathrm{THQ}=(\mathrm{EFr} \times \mathrm{ED} \times \mathrm{FiR} \times \mathrm{C} / \mathrm{RfD} \times \mathrm{BW} \times \mathrm{TA}) \times 10^{-3}
$$

where:

Efr-the exposure frequency (365 days/year);

ED-the exposure duration (70 years);

$\mathrm{FiR}$ - the fish ingestion rate (g/person/day);

$\mathrm{C}$ - the average concentration of mercury in foodstuffs ( $\mu \mathrm{g} / \mathrm{g}$ wet weight);

$\mathrm{RfD}$ - the Oral reference dose $\left(\mathrm{mg} / \mathrm{kg} /\right.$ day) of $\mathrm{Zn}, \mathrm{Cu}, \mathrm{Fe}$ and $\mathrm{Mn}\left(\mathrm{RfD}=3.00 \times 10^{-1}\right.$, $4.00 \times 10^{-2}, 7.00 \times 10^{-1}$ and $\left.1.4 \times 10^{-1}\right)($ US EPA 2017);

BW-the average body weight of local residents $(60 \mathrm{~kg})$ [29];

TA - the average exposure time (365 days/year $\times$ ED).

\subsection{The Combined Risk of Many Metals}

The TTHQ of heavy metals for individual foodstuff calculated as follows [30]:

TTHQ individual foodstuff $=$ THQ $($ toxicant 1$)+$ THQ $($ toxicant 2$)+\ldots \ldots+$ THQ $($ toxicant $n)$ $\mathrm{THQ}(\mathrm{Zn})+\mathrm{THQ}(\mathrm{Cu})+\mathrm{THQ}(\mathrm{Fe})+\mathrm{THQ}(\mathrm{Mn})$

The HI was calculated using the following pattern:

$$
\begin{gathered}
\text { HI = TTHQ }(\text { foodstuff } 1)+\text { TTHQ }(\text { foodstuff } 2)+\text { TTHQ }(\text { foodstuff } 3)+\text { TTHQ (foodstuff } 4)+ \\
\text { TTHQ }(\text { foodstuff } 5)+\text { TTHQ (foodstuff } 6)+ \text { TTHQ (foodstuff } 7)+ \text { TTHQ (foodstuff } 8)+ \\
\text { TTHQ (foodstuff 9) + TTHQ (foodstuff 10) }
\end{gathered}
$$

When the $\mathrm{HI}>1$, there may be a concern for potential health risks [30].

\subsection{Statistical Analysis}

The statistical analyses included calculations of the mean value and the standard deviations, performed with Microsoft Excel software (Microsoft 365, Microsoft Corporation, Redmond, WA, USA). Normal data distribution was analyzed by Shapiro-Wilk's test, whereas the variance homogeneity was analyzed by Levene's test. Due to the nonfulfillment of the requirements for the normal distribution of data and variance homogeneity, all the data was then analyzed by nonparametric Kruskal-Wallis, and Dunn's post-hoc tests were used to determine the statistical differences. The significance of difference of the mean values between the samples was determined with Statistica 13.3 (StatSoft, Inc., 2300 East 14th Street, Tulsa, OK, 74104, USA). Statistical significance was set at $p<0.05$. The results were expressed on a wet weight basis.

\section{Results}

Table 1 shows the results concerning the contents of heavy metals $(\mathrm{Cu}, \mathrm{Fe}, \mathrm{Mn}$ and $\mathrm{Zn}$ ) in the muscles of 10 fish species. Among the studied species of fish, significant high concentrations of zinc $(19.52 \mathrm{mg} / \mathrm{kg})$, copper $(0.77 \mathrm{mg} / \mathrm{kg})$ and iron $(6.95 \mathrm{mg} / \mathrm{kg})$ were observed in the muscle tissue of crucian carp $(p<0.05)$, whereas Walleye pollock had a higher content of manganese $(0.266 \mathrm{mg} / \mathrm{kg})(p<0.05)$.

Moreover, the following homogeneous groups were determined $(p>0.05)$.

Copper $(\mathrm{Cu})$ : (Blue grenadier, mackerel, rainbow trout, flounder, Gilthead seabream, perch and tench) and (tilapia and Walleye pollock).

Iron (Fe): (mackerel, rainbow trout, tench and perch); (Blue grenadier, Walleye pollock, tilapia and flounder) and (Gilthead seabream).

Manganese (Mn): (crucian carp) and (tench, perch, rainbow trout, tilapia, flounder, Gilthead seabream, Blue grenadier and mackerel). 
Zinc (Zn): (rainbow trout, flounder, Gilthead seabream, tench, Walleye pollock, perch, tilapia, mackerel and Blue grenadier).

Table 2 presents the results of covering the daily requirements for selected minerals $(\mathrm{Cu}, \mathrm{Fe}, \mathrm{Mn}$ and $\mathrm{Zn})$ after consuming an average portion of fish (150 g) for six age groups: A-boys 13-18 years old, B-girls 13-18 years old, C-men 19-50 years, D-women 19-50 years old, E-men 51-75 years old and F-women 51-75 years old.

According to the standards developed by the Food and Nutrition Institute for individual macronutrients, differences in the demands for nutrients between the six groups discussed were noted. Boys and men have higher demands for manganese and zinc, while girls and women have a higher demand for iron. As for the demand for copper, it was the same for the six discussed age groups.

In terms of covering the daily requirement after consuming an average portion of fish $(150 \mathrm{~g})$, crucian carp is distinguished from other species of fish. One portion of this species of fish covers the highest degree of demand for $\mathrm{Cu}(12.9 \%), \mathrm{Mn}(0.8-1 \%), \mathrm{Fe}(5.8-10.4 \%)$ and $\mathrm{Zn}(26.6-36.6 \%)$. These values are several times higher than in the case of covering the demand after consuming other species of fish. In the case of mackerel and Blue grenadier, the second-highest coverage was recorded after consuming a serving of $150 \mathrm{~g}$ per $\mathrm{Cu}(5.9 \%)$. A $150-\mathrm{g}$ portion of tench covers $6.7-9.2 \%$ of the demand for zinc. The lowest degree of the demand for $\mathrm{Cu}$ is covered by a portion of tilapia (2.7\%), of mackerel for $\mathrm{Mn}(0.1-0.2 \%)$, of Gilthead seabream for Fe (0.6-1.2\%) and of mackerel and Blue grenadier for Zn (4.1-5.7\% and $4.1-5.6 \%$ ).

From a nutritional point of view, the fish obtained in this study are safe for the consumer, as the fish quality indicators were below one. The THQ, TTHQ, TDHQ, and HI are presented in Table 3. The crucian carp had the highest THQ index for $\mathrm{Zn}, \mathrm{Fe}$ and $\mathrm{Cu}$, whereas the highest THQ for Mn was found in the muscles of Walleye pollock. The TTHQ was also the highest in crucian carp muscles. 
Table 2. Coverage of the demand (\%) for $\mathrm{Cu}, \mathrm{Fe}, \mathrm{Mn}$ and $\mathrm{Zn}$ after consuming an average portion of fish (150 g).

\begin{tabular}{|c|c|c|c|c|c|c|c|c|c|c|c|c|c|c|c|c|c|c|c|c|c|c|c|c|}
\hline \multirow{2}{*}{ Species } & \multicolumn{6}{|c|}{$\mathrm{Cu}$} & \multicolumn{6}{|c|}{$\mathrm{Fe}$} & \multicolumn{6}{|c|}{ Mn } & \multicolumn{6}{|c|}{$\mathrm{Zn}$} \\
\hline & A & B & $\mathrm{C}$ & D & E & F & A & B & $\mathrm{C}$ & D & E & F & A & B & $\mathrm{C}$ & D & $\mathrm{E}$ & F & A & B & $\mathrm{C}$ & D & $\mathrm{E}$ & $\mathrm{F}$ \\
\hline Crucian carp (Carassius carassius L.) & 12.9 & 12.9 & 12.9 & 12.9 & 12.9 & 12.9 & 8.7 & 7.0 & 10.4 & 5.8 & 10.4 & 10.4 & 0.8 & 1.1 & 0.8 & 1.0 & 0.8 & 1.0 & 26.6 & 32.5 & 26.6 & 36.6 & 26.6 & 36.6 \\
\hline $\begin{array}{l}\text { Flounder } \\
\text { (Platichthus flesus L.) }\end{array}$ & 4.4 & 4.4 & 4.4 & 4.4 & 4.4 & 4.4 & 1.3 & 1.0 & 1.5 & 0.9 & 1.5 & 1.5 & 0.2 & 0.3 & 0.2 & 0.3 & 0.2 & 0.3 & 5.6 & 6.8 & 5.6 & 7.7 & 5.6 & 7.7 \\
\hline $\begin{array}{c}\text { Mackerel } \\
\text { (Scomber scombrus L.) }\end{array}$ & 5.9 & 5.9 & 5.9 & 5.9 & 5.9 & 5.9 & 2.3 & 1.8 & 2.7 & 1.5 & 2.7 & 2.7 & 0.1 & 0.2 & 0.1 & 0.2 & 0.1 & 0.2 & 4.1 & 5.0 & 4.1 & 5.7 & 4.1 & 5.7 \\
\hline $\begin{array}{l}\text { Blue grenadier } \\
\text { (Macruronus novaezelandiae Hector) }\end{array}$ & 5.9 & 5.9 & 5.9 & 5.9 & 5.9 & 5.9 & 1.4 & 1.2 & 1.7 & 1.0 & 1.7 & 1.7 & 0.2 & 0.3 & 0.2 & 0.3 & 0.2 & 0.3 & 4.1 & 5.0 & 4.1 & 5.6 & 4.1 & 5.6 \\
\hline $\begin{array}{c}\text { Perch } \\
\text { (Perca fluviatilis L.) }\end{array}$ & 3.9 & 3.9 & 3.9 & 3.9 & 3.9 & 3.9 & 1.9 & 1.5 & 2.3 & 1.3 & 2.3 & 2.3 & 0.5 & 0.7 & 0.5 & 0.6 & 0.5 & 0.6 & 4.2 & 5.1 & 4.2 & 5.8 & 4.2 & 5.8 \\
\hline $\begin{array}{c}\text { Tench } \\
\text { (Tinca tinca L.) }\end{array}$ & 3.8 & 3.8 & 3.8 & 3.8 & 3.8 & 3.8 & 2.1 & 1.6 & 2.5 & 1.4 & 2.5 & 2.5 & 0.6 & 0.8 & 0.6 & 0.7 & 0.6 & 0.7 & 4.5 & 5.6 & 4.5 & 6.2 & 4.5 & 6.2 \\
\hline $\begin{array}{c}\text { Tilapia } \\
\text { (Oreochromis niloticus L.) }\end{array}$ & 2.7 & 2.7 & 2.7 & 2.7 & 2.7 & 2.7 & 1.3 & 1.1 & 1.6 & 0.9 & 1.6 & 1.6 & 0.4 & 0.5 & 0.3 & 0.4 & 0.3 & 0.4 & 4.2 & 5.1 & 4.2 & 5.7 & 4.2 & 5.7 \\
\hline $\begin{array}{l}\text { Walleye pollock (Gadus } \\
\text { chalcogrammus Pallas) }\end{array}$ & 4.8 & 4.8 & 4.8 & 4.8 & 4.8 & 4.8 & 1.4 & 1.1 & 1.7 & 0.9 & 1.7 & 1.7 & 1.8 & 2.5 & 1.7 & 2.2 & 1.7 & 2.2 & 4.5 & 5.4 & 4.5 & 6.1 & 4.5 & 6.1 \\
\hline
\end{tabular}

Explanation: A—boys (13-18 years old); B-girls (13-18 years old); C—man (19-50 years old); D—woman (19-50 years old); E—man (51-75 years old); F-woman (51-75 years old). 
Table 3. The hazard quotient calculated for metal contents in the muscle tissues of fish.

\begin{tabular}{|c|c|c|c|c|c|c|}
\hline Species & $\mathrm{Cu}$ & $\mathrm{Fe}$ & Mn & $\mathrm{Zn}$ & & \\
\hline & & THQ & & & TTHQ & HI \\
\hline $\begin{array}{c}\text { Crucian carp } \\
\text { (Carassius carassius L.) }\end{array}$ & 0.0112 & 0.0058 & 0.0005 & 0.0377 & 0.0551 & \\
\hline $\begin{array}{c}\text { Flounder } \\
\text { (Platichthys flesus L.) }\end{array}$ & 0.0038 & 0.0008 & 0.0001 & 0.0079 & 0.0127 & \\
\hline $\begin{array}{l}\text { Gilthead seabream } \\
\text { (Sparus aurata L.) }\end{array}$ & 0.0035 & 0.0006 & 0.0001 & 0.0077 & 0.0120 & \\
\hline $\begin{array}{c}\text { Mackerel } \\
\text { (Scomber scombrus L.) }\end{array}$ & 0.0051 & 0.0015 & 0.0001 & 0.0059 & 0.0126 & \\
\hline $\begin{array}{c}\text { Blue grenadier } \\
\text { (Macruronus novaezelandiae Hector) }\end{array}$ & 0.0052 & 0.0010 & 0.0001 & 0.0058 & 0.0120 & 0.164 \\
\hline $\begin{array}{c}\text { Perch } \\
\text { (Perca fluviatilis L.) }\end{array}$ & 0.0033 & 0.0013 & 0.0003 & 0.0059 & 0.0109 & \\
\hline $\begin{array}{c}\text { Rainbow trout } \\
\text { (Oncorhynchus mykiss Walb.) }\end{array}$ & 0.0039 & 0.0015 & 0.0003 & 0.0095 & 0.0152 & \\
\hline $\begin{array}{c}\text { Tench } \\
\text { (Tinca tinca L.) }\end{array}$ & 0.0033 & 0.0014 & 0.0004 & 0.0064 & 0.0115 & \\
\hline $\begin{array}{c}\text { Tilapia } \\
\text { (Oreochromis niloticus L.) }\end{array}$ & 0.0024 & 0.0009 & 0.0002 & 0.0059 & 0.0094 & \\
\hline $\begin{array}{c}\text { Walleye pollock } \\
\text { (Gadus chalcogrammus Pallas) }\end{array}$ & 0.0040 & 0.0009 & 0.0011 & 0.0063 & 0.0125 & \\
\hline TDHQ & 0.0456 & 0.0156 & 0.0032 & 0.0991 & & \\
\hline $\begin{array}{c}\text { RfD } \\
(\mathrm{mg} / \mathrm{kg} / \text { day })\end{array}$ & $4.00 \times 10^{-2}$ & $7.00 \times 10^{-1}$ & $1.4 \times 10^{-1}$ & $3.00 \times 10^{-1}$ & & \\
\hline
\end{tabular}

\section{Discussion}

It is known that fish are a rich source of many nutrients, including macronutrients necessary for the proper functioning of living organisms. Some of them are classified as heavy metals, and their excess poses a risk of human disease. The current study focused on checking the quality of commercial fish in terms of the zinc, copper, iron and manganese contents. Prashanth et al. [31] stated that these metals are essential, because they play an important role in biological processes. Among vertebrates, fish are unique, as they have two routes of metal acquisition: from water via the gills and from the diet via the gut (direct and trophic uptake routes). The direct uptake route is more important, because the gills are the main target organ for metal toxicity in fish [32]. Ali and Khan [33] and Garai et al. [34] reported on the role of fish in biological systems. Their article also mentioned that heavy metals may enter the fish body directly from the water and sediments, through the gills/skin and from its food/prey through the digestive tract. According to Jovanović et al. [35], organisms living in the aquatic environment absorb metals directly from the environment and contaminated water and food, then accumulate them in their tissues and introduce them into the food chain, which is a problem for humans.

The current research concerned the analysis of fish popular on the market and popular for consumers in terms of safety for the consumer. The supplies of fish to the Polish market come from sources such as aquaculture inland waterways, sea fishing and mainly imported. Vietnamese pangasius has been present on the Polish market since 2006. The second species that entered the Polish market was tilapia. The most frequently chosen species are: pollock, cod, carp, trout, pangasius and salmon. Salmon, begins a list of the five most favorite fish, followed by cod, mackerel, carp and tuna [36], The consumer choices in the market for fish, seafood and its products against the background of the situation in the fishing industry [37]. However, it is known that research fish are popular and often eaten around the world. 
The ecological role of fish should not be forgotten. Ali and Khan [33] reported that the pollution of freshwater ecosystems and fish is a serious issue of environmental, ecological and economic importance. We must not forget about other aquatic ecosystems and the fish that live there. The ecological role of fish was also highlighted by Villéger et al. [38]. The authors wrote that, due to the increasing anthropogenic pressure in freshwater and marine ecosystems, our research should focus on the functions that are related to their main ecological roles in aquatic ecosystems. For most aquatic ecosystems, fish are prey to many other animal species (including other fish), and therefore, their diversity and biomass affect the aquatic predator demographics and, more generally, the structure of aquatic food chains (from pure herbivores to top predators, including various levels of omnivory and detritivory) and adjacent terrestrial ecosystems through the predation of terrestrial animals. It is therefore important to characterize fish defense strategies, as these functional traits affect species adaptation, the structure of fish communities and the functioning of aquatic ecosystems. Winemiller [39] reported that there is a special variation in ecological relationships between different species, as well as different populations within a given species. Aquatic and estuary ecosystems are very sensitive to pollution and landscape changes caused by human activity, as a result of which, fish abundance and diversity have declined in many regions of the world. Taking into account the fact that practically each of the studied species (Table 1) occurs in a different ecosystem, we cannot determine the exact ecological relationships between the described species. The differences between these species may result from many factors, both abiotic and biotic. We have marine and freshwater fish here. There are farmed fish in the studied group (rainbow trout and tilapia) fed with composed feed that are not exposed to such a degree to contact with heavy metals. There are also interspecies differences caused, among other things, by the diet and their place in the food chain. We have nonpredatory fish, which eat mainly bottom food (crucian carp and tench), as well as predatory fish (perch, mackerel, Walleye pollock and Blue grenadier) (Table 1). All these factors influenced the observed concentrations of heavy metals in the muscle tissue of the tested fish. The fact that abiotic and biotic factors influence the contents of heavy metals has been mentioned in earlier publications by other authors [33,40-46].

According to the authors' knowledge, there are no acceptable standards in Poland regarding the contents of elements in fish. Hence, it was decided to compare the recorded levels of the elements with the regulations contained in Table 4.

Table 4. Permitted levels of heavy metals in fish ( $\mathrm{mg} / \mathrm{kg}$ wet weight) described in the different literature.

\begin{tabular}{cccccc}
\hline References & & Cu & Fe & Zn & Mn \\
\hline FAO (1983) & {$[47]$} & 30 & - & $30-150$ & - \\
FAO/WHO (1989) & {$[48]$} & 30 & - & 40 & 2.5 \\
Turkish Food Codex (TFC, 2002) & {$[49]$} & 20 & 50 & 50 & 20 \\
Anonymous (2005) & {$[50]$} & 30 & 30 & 100 & \\
$\begin{array}{c}\text { Ministry of Agriculture, Fisheries } \\
\text { and Food (MAFF, 2000) }\end{array}$ & {$[51]$} & 20 & - & 50 & - \\
\hline
\end{tabular}

On this basis, it was concluded that the levels of $\mathrm{Cu}, \mathrm{Zn}, \mathrm{Fe}$ and $\mathrm{Mn}$ in the studied fish species were lower than the maximum levels (Table 1). Bobrowska-Korczak et al. [52] found a that health risk assessment due to contamination is necessary; therefore, monitoring plays a vital role in food safety, which can help introduce national legislation and global standards aimed at reducing or even eliminating exposure to contaminants.

According to Rožič et al. [53], the $\mathrm{Zn}$ and $\mathrm{Cu}$ values in cultured and wild seabream were below the permissible levels ( 50 and $20 \mathrm{mg} / \mathrm{kg}$, respectively) [49]. The values given by the authors were higher than the values determined for this species of fish covered by the research in this paper (Table 1). The muscles of tench caught in the summer from the Damsa Dam Lake included the following levels of $\mathrm{Zn}, \mathrm{Fe}, \mathrm{Cu}$ and $\mathrm{Mn}$ : 36.0323, 47.304, 0.5146 and $0.8655 \mathrm{mg} / \mathrm{kg}$ wet weight, respectively. These values were much higher than those 
presented in this study but were safe to be consumed (Table 1) [54]. Seabream from the Sinop Coast of the Black Sea (Turkey) also had higher contents of Zn (10.72-22.34 mg/kg) and $\mathrm{Cu}(3.48-5.21 \mathrm{mg} / \mathrm{kg})$, but these values were within the limits set by the Commission Regulation and Turkish Food Codex [55]. The muscles of flounder from the Baltic Sea (Poland) contained $\mathrm{Zn}$ and $\mathrm{Cu}$ values as follows: $14-27 \mathrm{mg} / \mathrm{kg}$ dry weight and 0.3-1.1 dry weight [56]. According to Perugini et al. [57], the contents of $\mathrm{Cu}$ and $\mathrm{Zn}$ in the muscles of Atlantic mackerel were 1.32 and $38.52 \mathrm{mg} / \mathrm{kg}$ wet weight, whereas, in the muscle tissue of perch from Anzali Wetland (Iran), they were 10.02 and $27.76 \mathrm{mg} / \mathrm{kg}$ wet weight [58]. These values were also higher than those found in the current study for this species of fish (Table 1). The current study also showed significant differences in the contents of copper and manganese in the muscles of seabream and tilapia. Such differences were not noted for zinc (Table 1), while Elnabris et al. [59] did not find statistical differences in the contents of these elements in these fish species. The same authors stated that the average daily intake of metals decreased as follows: $\mathrm{Zn}>\mathrm{Mn} \approx \mathrm{Cu}$ and was 43.2-239.4, 4.4-9.7 and 2.9-10.6, $\mu \mathrm{g} /$ day/person, respectively. The average daily fish intake in Turkey is $20 \mathrm{~g}$ per person, while the EDI values ( $\mu \mathrm{g} /$ day $/ 70 \mathrm{~kg}$ body weight) calculated by Türkmen et al. [60] were 296.0 for $\mathrm{Zn}, 22.0$ for $\mathrm{Cu}, 1028$ for Fe and 21.2 for $\mathrm{Mn}$ and were far below the recommended limits. Hence, consuming these fish did not pose a threat to human health. Abubakar et al. [61] noted a much higher iron content in the muscles of Scomber scombrus from Nigeria $(11.453 \mathrm{mg} / \mathrm{kg}$ and $21.873 \mathrm{mg} / \mathrm{kg}$ ) and found that these values were above the recommended safety limits provided by the FAO/WHO. Rubio et al. [62] found that a daily average consumption of $45.8 \mathrm{~g}$ of Gilthead seabream from Tenerife fish farms (Spain) provided $0.29 \mathrm{mg}$ of $\mathrm{Fe}(1.6-3.6 \%$ of the RDA), $0.062 \mathrm{mg}$ of $\mathrm{Cu}(6.89-8.86 \%$ of the RDA) and $0.83 \mathrm{mg}$ of $\mathrm{Zn}$ (7.58-10.43\% of the RDA). According to the RDA (Recommended Dietary Allowances) standard, the daily requirement for $\mathrm{Cu}$ is $0.9 \mathrm{mg} /$ day in all analyzed age groups. The demand for Mn ranges from $1.6 \mathrm{mg} /$ day (girls 13-18 years old) to $2.3 \mathrm{mg} /$ day (men 19-50 years and 51-75 years old). The daily requirement for Fe is dependent on sex and age, and it ranges from $10 \mathrm{mg} /$ day (men 19-50 years old and men and women 51-75 years old) to $18 \mathrm{mg}$ / day (women 19-50 years old). The daily $\mathrm{Zn}$ requirement ranges from $8 \mathrm{mg}$ / day (women 19-50 and women 51-75) to $11 \mathrm{mg} /$ day (boys 13-18 years old, men 19-50 years old and men 51-75 years old) [63]. Individual types of fish meet the highest demand for the discussed minerals among girls aged 13-18 for Mn (0.2-2.5\%), men aged $19-50$ and men and women aged $51-75(1.2-10.4 \%)$ for Fe (1.2-10.4\%) and women aged 19-50 (5.6-36.6\%) and 51-75 years (5.6-36.6) for $\mathrm{Zn}$, due to the lowest demand of this age group for these macronutrients.

Many of the heavy metals are micronutrients and trace elements necessary for the proper functioning of the body, e.g., copper and zinc, and only after exceeding a certain level in the body can they cause a toxic effect and interfere with the absorption of other elements.

Budjono and Hasbi [64] studied six important commercial fish species, including Oreochromis niloticus, and found that the muscles of all fish meet the limits of $\mathrm{Zn}$ for human consumption. According to Bobrowska-Korczak et al. [52], crucian carp contained more $\mathrm{Cu}$ than perch and flounder (crucian carp $\approx$ perch $>$ flounder), although there were no statistically significant differences between crucian carp and perch. This was not in accordance with the authors' studies (Table 1).

For rainbow trout and other fish species, it was confirmed by Zapata et al. [65] that zinc is present in the muscle tissue, followed by iron and copper. Kalyoncu et al. [66] studied the metal contents in the muscles of fish and observed the following sequences: $\mathrm{Zn}>\mathrm{Mn}>$ $\mathrm{Fe}>\mathrm{Cu}$ (tench) and $\mathrm{Zn}>\mathrm{Fe}>\mathrm{Mn}>\mathrm{Cu}$ (crucian carp) (Turkey), which were inconsistent with current study (Table 1) and other authors [67]. Fidan et al. [68] examined the contents of heavy metals in crucian carp muscles and noted the same order as in the current study. Yousif et al. [69], based on the research of other investigators, observed that the elements were arranged in the following order: $\mathrm{Fe}>\mathrm{Zn}>\mathrm{Cu}>\mathrm{Mn}$. The findings included fish and other aquatic organisms from polluted areas (rivers and the Karachi Coast, Pakistan). In the muscles of Gilthead seabream purchased from the Bulgarian market, the predominant 
metal was $\mathrm{Zn}$, followed by $\mathrm{Fe}, \mathrm{Cu}$ and $\mathrm{Mn}$ [70]. This was in accordance with the results in the current study (Table 1). A previous study [45] also confirmed the same order of the elements in the muscles of tench and perch, while Rakocevic et al. [44] found that this sequence was as follows in perch muscles: $\mathrm{Zn}>\mathrm{Fe}>\mathrm{Mn}>\mathrm{Cu}$.

The total target hazard index in wild and farmed seabream from coastal Algeria was less than one [71]. Similarly, the consumption of both farmed species (seabass and Gilthead seabream) from four Mediterranean fish farms should be considered safe due to the contents of the metals for human health [72]. The THQ values for the muscles of cultured Gilthead seabream from the Mediterranean (Corsican Coast) were also lower than 1 ( 0.103 for $\mathrm{Zn}$, 0.002 for $\mathrm{Fe}, 0.004$ for $\mathrm{Cu}$ and 0.001 for $\mathrm{Mn}$ in terms of a 70-kg adult consuming $427 \mathrm{~g}$ of fish/week [73]. The THQ (0.0002-0.0186) and individual foodstuff TTHQ (0.132-0.653) for the muscles of roach, bream (Abramis brama (L.)), pike (Esox lucius (L.)) and Eurasian perch were below 1, where mercury was also taken into account in calculating the TTHQ [30]. Similar results were achieved when examining the muscle tissues of European perch and roach from Lake Pluszne [74]. These results were confirmed by the current study (Table 3).

\section{Conclusions}

The crucian carp is considered a tasty and economically valuable fish. The research showed that, among other fish species bought in stores, crucian carp contained the highest levels of heavy metals, which, despite their name, are needed for the functioning of living organisms. The quality indicators used in this study showed that crucian carp is also a safe fish food, similar to other fish, because the indicators (THQ and HI) were below one. According to our knowledge, there are no acceptable standards in Poland regarding the contents of heavy metals studied in fish determined by us. Hence, it was decided to compare the marked levels of the elements with the Regulations of FAO (1983) and FAO/WHO (1989). On this basis, it was concluded that the levels of $\mathrm{Cu}, \mathrm{Zn}, \mathrm{Fe}$ and $\mathrm{Mn}$ in fish species were lower than the maximum levels. Nevertheless, research on the content of all heavy metals should be continued.

Author Contributions: J.Ł. had the original idea for the study and wrote the manuscript; R.P.-F. wrote the "Introduction" and conducted the statistical analysis; J.Ł. and M.J.Ł. collected and analyzed the data; A.P. wrote the results covering the daily requirements for the selected minerals and counted the data used to create the tables. M.J.Ł. contributed to the writing of the "References" and the revision process. All authors have read and agreed to the published version of the manuscript.

Funding: The research was financed by Statutory Theme No. 17.610-003-110.

Institutional Review Board Statement: Fish were bought from the local market., they were already dead. According to European and Polish Law, the research done on the commercially caught fishes tissue is free to obtain permission on Local Ethical Commision.

Informed Consent Statement: Not applicable.

Data Availability Statement: Not applicable.

Conflicts of Interest: The authors declare that there are no conflict of interest regarding the publication of this article.

\section{References}

1. Statistical Yearbook of Agriculture; 2020; p. 322. Available online: https://stat.gov.pl/en/topics/statistical-yearbooks/statisticalyearbooks / statistical-yearbook-of-agriculture-2020,6,15.html (accessed on 25 November 2021). (In Polish)

2. Available online: https://ec.europa.eu/oceans-and-fisheries/facts-and-figures/facts-and-figures-common-fisheries-policy/ consumption_en (accessed on 15 December 2021).

3. Kieliszewska, M. Światowy rynek ryb i owoców morza. In Rynek Ryb—Stan i Perspektywy. Analizy Rynku; Hryszko, K., Ed.; Instytut Ekonomiki Rolnictwa I Gospodarki Żywnościowej-Państwowy Instytut Badawczy: Gdynia, Poland, 2020; Volume 31, pp. 11-16. (In Polish)

4. Wall, R.; Ross, R.P.; Fitzgerald, G.F.; Stanton, C. Fatty acids from fish: The anti-inflammatory potential of long-chain omega-3 fatty acids. Nutr. Rev. 2010, 68, 280-289. [CrossRef] [PubMed] 
5. Gladyshev, M.I.; Glushchenko, L.A.; Makhutova, O.N.; Rudchenko, A.E.; Shulepina, S.P.; Dubovskaya, O.P.; Zuev, I.; Kolmakov, V.I.; Sushchik, N.N. Comparative Analysis of Content of Omega-3 Polyunsaturated Fatty Acids in Food and Muscle Tissue of Fish from Aquaculture and Natural Habitats. Contemp. Probl. Ecol. 2018, 11, 297-308. [CrossRef]

6. Ismail, H.M. The role of omega-3 fatty acids in cardiac protection: An overview. Front. Biosci. 2005, 10, 1079-1088. [CrossRef] [PubMed]

7. Johnson, M.; Bradford, C. Omega-3, Omega-6 and Omega-9 Fatty Acids: Implications for Cardiovascular and Other Diseases. J. Glycom. Lipidom. 2014, 4, 1-8. [CrossRef]

8. $\quad$ Bowen, K.J.; Harris, W.S.; Kris-Etherton, P.M. Omega-3 Fatty Acids and Cardiovascular Disease: Are There Benefits? Curr. Treat. Options Cardiovasc. Med. 2016, 18, 69. [CrossRef] [PubMed]

9. Salvador, A.M.; García-Maldonado, E.; Gallego-Narbón, A.; Zapatera, B.; Vaquero, M.P. Fatty Acid Profile and Cardiometabolic Markers in Relation with Diet Type and Omega-3 Supplementation in Spanish Vegetarians. Nutrients 2019, 11, 1659. [CrossRef]

10. Schneedorferová, I.; Tomčala, A.; Valterová, I. Effect of heat treatment on the $n-3 / n-6$ ratio and content of polyunsaturated fatty acids in fish tissues. Food Chem. 2015, 176, 205-211. [CrossRef]

11. Jia, Y.; Wang, L.; Cao, J.; Lin, W.; Yang, Z. Trace elements in four freshwater fish from a mine-impacted river: Spatial distribution, species-specific accumulation, and risk assessment. Environ. Sci. Pollut. Res. 2018, 25, 8861-8870. [CrossRef]

12. Łuczyńska, J.; Paszczyk, B. Health Risk Assessment of Heavy Metals and Lipid Quality Indexes in Freshwater Fish from Lakes of Warmia and Mazury Region, Poland. Int. J. Environ. Res. Public Health 2019, 16, 3780. [CrossRef]

13. Pietrzak-Fiecko, R.; Parol, J. Chloroorganic insecticides in the fat of different assortment of rainbow trout (Oncorhynchus mykiss) meat. Bull. Vet. Inst. Pulawy 2014, 58, 597-602. [CrossRef]

14. Georgieva, E.; Yancheva, V.; Stoyanova, S.; Velcheva, I.; Iliev, I.; Vasileva, T.; Bivolarski, V.; Petkova, E.; László, B.; Nyeste, K.; et al. Which Is More Toxic? Evaluation of the Short-Term Toxic Effects of Chlorpyrifos and Cypermethrin on Selected Biomarkers in Common Carp (Cyprinus carpio, Linnaeus 1758). Toxics 2021, 9, 125. [CrossRef] [PubMed]

15. Stoyanova, S.; Nyeste, K.; Georgieva, E.; Uchikov, P.; Velcheva, I.; Yancheva, V. Toxicological impact of a neonicotinoid insecticide and an organophosphorus fungicide on bighead carp (Hypophthalmichthys nobilis Richardson, 1845) gills: A comparative study. North West. J. Zool. 2020, 16, e191401.

16. Betts, J.T.; Mendoza Espinoza, J.F.; Dans, A.J.; Jordan, C.A.; Mayer, J.L.; Urquhart, G.R. Fishing with Pesticides Affects River Fisheries and Community Health in the Indio Maíz Biological Reserve, Nicaragua. Sustainability 2020, 12, 10152. [CrossRef]

17. Nyeste, K.; Dobrocsi, P.; Czeglédi, I.; Czédli, H.; Harangi, S.; Baranyai, E.; Simon, E.; Nagy, S.A.; Antal, L. Age and diet-specific trace element accumulation patterns in different tissues of chub (Squalius cephalus): Juveniles are useful bioindicators of recent pollution. Ecol. Indic. 2019, 101, 1-10. [CrossRef]

18. Brzozowska, A. Składniki mineralne. In Żywienie Człowieka. Podstawy Nauki o Żywieniu; Gawęcki, J., Hryniewiecki, L., Eds.; PWN: Warsaw, Poland, 1998; pp. 23-40. (In Polish)

19. Nieder, R.; Benbi, D.K.; Reichl, F.X. Microelements and Their Role in Human Health. In Soil Components and Human Health; Springer: Dordrecht, Germany, 2018. [CrossRef]

20. European Food Safety Authority (EFSA). Dietary Reference Values for Nutrients Summary Report. EFSA Support. Public 2017, 14, e15121. [CrossRef]

21. Marín-Guirao, L.; Lloret, J.; Marin, A. Carbon and nitrogen stable isotopes and metal concentration in food webs from a mining-impacted coastal lagoon. Sci. Total Environ. 2008, 393, 118-130. [CrossRef]

22. Lall, S.P.; Kaushik, S.J. Nutrition and Metabolism of Minerals in Fish. Animals 2021, 11, 2711. [CrossRef]

23. Han, S.; Auger, C.; Castonguay, Z.; Appanna, V.P.; Thomas, S.C.; Appanna, V.D. The unravelling of metabolic dysfunctions linked to metal-associated diseases by blue native polyacrylamide gel electrophoresis. Anal. Bioanal. Chem. 2013, 405, 1821-1831. [CrossRef]

24. Manea, D.N.; Ienciu, A.A.; Ştef, R.; Şmuleac, I.L.; Gergen, I.I.; Nica, D.V. Health Risk Assessment of Dietary Heavy Metals Intake from Fruits and Vegetables Grown in Selected Old Mining Areas-A Case Study: The Banat Area of Southern Carpathians. Int. J. Environ. Res. Public Health 2020, 17, 5172. [CrossRef]

25. Serviere-Zaragoza, E.; Lluch-Cota, S.E.; Mazariegos-Villarreal, A.; Balart, E.F.; Valencia-Valdez, H.; Méndez-Rodríguez, L.C. Cadmium, Lead, Copper, Zinc, and Iron Concentration Patterns in Three Marine Fish Species from Two Different Mining Sites inside the Gulf of California, Mexico. Int. J. Environ. Res. Public Health. 2021, 18, 844. [CrossRef]

26. Whiteside, P.; Miner, B. Pye. Unicam Atomic Absorption Data Book; Pye Unicam LTD: Cambridge, UK, 1984.

27. Ahmed, K.; Baki, M.A.; Kundu, G.K.; Islam, S.; Islam, M.; Hossain, M. Human health risks from heavy metals in fish of Buriganga river, Bangladesh. SpringerPlus 2016, 5, 1697. [CrossRef]

28. US EPA. Regional Screening Level (RSL) Summary Table; US EPA: Washington, DC, USA, 2017.

29. Polak-Juszczak, L.; Nermer, T. Methylmercury and Total Mercury in Eels, Anguilla anguilla, from Lakes in Northeastern Poland: Health Risk Assessment. EcoHealth 2016, 13, 582-590. [CrossRef] [PubMed]

30. Saha, N.; Zaman, M.R. Evaluation of possible health risks of heavy metals by consumption of foodstuffs available in the central market of Rajshahi City, Bangladesh. Environ. Monit. Assess. 2013, 185, 3867-3878. [CrossRef] [PubMed]

31. Prashanth, L.; Kattapagari, K.K.; Chitturi, R.T.; Baddam, V.R.R.; Prasad, L.K. A review on role of essential trace elements in health and disease. J. Dr. NTR Univ. Health Sci. 2015, 4, 75-85. [CrossRef] 
32. Sauliute, G.; Svecevicius, G. Heavy metal interactions during accumulation via direct route in fish: A review. Zool. Ecol. 2015, 25, 77-86. [CrossRef]

33. Ali, H.; Khan, E. Bioaccumulation of non-essential hazardous heavy metals and metalloids in freshwater fish. Risk to human health. Environ. Chem. Lett. 2018, 16, 903-917. [CrossRef]

34. Garai, P.; Banerjee, P.; Mondal, P.; Chandra Saha, N. Effect of heavy metals on fishes: Toxicity and bioaccumulation. J. Toxicol. Clin. Toxicol. 2021, 11, S18.

35. Jovanović, D.A.; Marković, R.V.; Teodorović, V.B.; Šefer, D.S.; Krstić, M.P.; Radulović, S.B.; Ćirić, J.; Janjić, J.M.; Baltić, M.Ž. Determination of heavy metals in muscle tissue of six fish species with different feeding habits from the Danube River, Belgradepublic health and environmental risk assessment. Environ. Sci. Pollut. Res. 2017, 24, 11383-11391. [CrossRef]

36. Kosicka-Gęska, M.; Ładecka, Z. Conditions and trends of fish consumption in Poland. Stow. Ekon. Rol. Agrobiz. Rocz. Naukowe 2012, 14, 238-244. (In Polish)

37. Rejman, K.; Kowrygo, B.; Janowska, M. Consumers' choices in the market for fish, seafood and its products against the background of the situation in the fish branch. Handel Wewnettrzny 2015, 3, 216-226. (In Polish)

38. Villéger, S.; Brosse, S.; Mouchet, M.; Mouillot, D.; Vanni, M.J. Functional ecology of fish: Current approaches and future challenges. Aquat. Sci. 2017, 79, 783-801. [CrossRef]

39. Winemiller, K. Fish ecology. In Encyclopedia of Environmental Biology; Academic Press: San Diego, CA, USA, 1995; Volume 2, pp. 49-65.

40. Jezierska, B.; Witeska, M. The metal uptake and accumulation in fish living in polluted waters. In Soil and Water Pollution Monitoring, Protection and Remediation; Springer: Dordrecht, The Netherlands, 2006; Volume 69, pp. 107-114. [CrossRef]

41. Jakimska, A.; Konieczka, P.; Skóra, K.; Namieśnik, J. Bioaccumulation of metals in tissues of marine animals, Part II: Metal concentrations in animal tissues. Pol. J. Environ. Stud. 2011, 20, 1127-1146.

42. Järv, L.; Kotta, J.; Simm, M. Relationship between biological characteristics of fish and their contamination with trace metals: A case study of perchPerca fluviatilisL. in the Baltic Sea. Proc. Estonian Acad. Sci. 2013, 62, 193-201. [CrossRef]

43. Merciai, R.; Guasch, H.; Kumar, A.; Sabater, S.; García-Berthou, E. Trace metal concentration and fish size: Variation among fish species in a Mediterranean river. Ecotoxicol. Environ. Saf. 2014, 107, 154-161. [CrossRef]

44. Rakocevic, J.; Sukovic, D.; Maric, D. Distribution and relationships of eleven trace elements in muscle of six fish species from Skadar Lake (Montenegro). Turk. J. Fish. Aquat. Sci. 2018, 18, 647-657. [CrossRef]

45. Łuczyńska, J.; Tońska, E.; Paszczyk, B.; Łuczyński, M.J. The relationship between biotic factors and the content of chosen heavy metals ( $\mathrm{Zn}, \mathrm{Fe}, \mathrm{Cu}$ and $\mathrm{Mn}$ ) in six wild freshwater fish species collected from two lakes (Łańskie and Pluszne) located in northeastern Poland. Iran. J. Fish. Sci. 2020, 19, 421-442.

46. Saah, S.A.; Adu-Poku, D.; Boadi, N.O. Heavy metal contamination and water quality of selected fish ponds at Sunyani, Ghana: A comparison with WHO standards. Chem. Int. 2021, 7, 181-187. [CrossRef]

47. FAO. Compilation of Legal Limits for Hazardous Substances in Fish and FISHERY Products; FAO Fishery Circular No. 464; FAO: Rome, Italy, 1983; pp. 5-100. Available online: http:/ / www.fao.org/docrep/014/q5114e/q5114e.pdf (accessed on 25 November 2021).

48. FAO; WHO. Evaluation of Certain Food Additives and the Contaminants Mercury, Lead and Cadmium; WHO Technical Report Series, No 505; WHO: Geneva, Switzerland, 1989. Available online: https://apps.who.int/iris/bitstream/10655/40985/WHO_TRS_505.pdf (accessed on 25 November 2021).

49. Tanır, Ö.Z. Determination of heavy metals in some tissues of four fish species from the Karasu River (Erzincan, Turkey) for public consumption. Oceanol. Hydrobiol. Stud. 2021, 50, 232-246. [CrossRef]

50. Anonymous. By-Law on Toxins, Metals, Metalloids and Other Harmful Substances in Food; Narodne Novine No. 16/05; Ministry of Health and Social Care, Republic of Croatia: Zagreb, Croatia, 2005.

51. MAFF. Monitoring and surveillance of non-radioactive contaminants in the aquatic environment and activities regulating the disposal of wastes at sea. In Aquatic Environment Monitoring Report No. 52; Center for Environment, Fisheries and Aquaculture Science: Lowestoft, UK, 2000.

52. Bobrowska-Korczak, B.; Stawarska, A.; Szterk, A.; Ofiara, K.; Czerwonka, M.; Giebułtowicz, J. Determination of Pharmaceuticals, Heavy Metals, and Oxysterols in Fish Muscle. Molecules 2021, 26, 1229. [CrossRef]

53. Rožič, P.Ž.; Dolenec, T.; Baždarić, B.; Karamarko, V.; Kniewald, G.; Dolenec, M. Element levels in cultured and wild sea bass (Dicentrarchus labrax) and gilthead sea bream (Sparus aurata) from the Adriatic Sea and potential risk assessment. Environ. Geochem. Health 2014, 36, 19-39. [CrossRef]

54. Mert, R.; Alaş, A.; Bulut, S.; Özcan, M.M. Determination of heavy metal contents in some freshwater fishes. Environ. Monit. Assess. 2014, 186, 8017-8022. [CrossRef] [PubMed]

55. Bat, L.; Sezgin, M.; Ustun, F.; Sahin, F. Heavy metal concentrations in ten species of fishes caught in Sinop coastal waters of the Black Sea, Turkey. Turk. J. Fish. Aquat. Sci. 2012, 12, 371-376. [CrossRef]

56. Polak-Juszczak, L. Trace metals in flounder, Platichthys flesus (Linnaeus, 1758), and sediments from the Baltic Sea and the Portuguese Atlantic coast. Environ. Sci. Pollut. Res. 2013, 20, 7424-7432. [CrossRef] [PubMed]

57. Perugini, M.; Visciano, P.; Manera, M.; Zaccaroni, A.; Olivieri, V.; Amorena, M. Heavy metal (As, Cd, Hg, Pb, Cu, Zn, Se) concentrations in muscle and bone of four commercial fish caught in the central Adriatic Sea, Italy. Environ. Monit. Assess. 2014, 186, 2205-2213. [CrossRef] [PubMed] 
58. Yazdi, R.B.; Ebrahimpour, M.; Mansouri, B.; Rezaei, M.R.; Babaei, H. Contamination of Metals in Tissues of Ctenopharyngodon idella and Perca fluviatilis, from Anzali Wetland, Iran. Bull. Environ. Contam. Toxicol. 2012, 89, 831-835. [CrossRef] [PubMed]

59. Elnabris, K.J.; Muzyed, S.K.; El-Ashgar, N.M. Heavy metal concentrations in some commercially important fishes and their contribution to heavy metals exposure in Palestinian people of Gaza Strip (Palestine). J. Assoc. Arab Univ. Basic Appl. Sci. 2013, 13, 44-51. [CrossRef]

60. Türkmen, M.; Türkmen, A.; Tepe, Y. Comparison of Metals in Tissues of Fish from Paradeniz Lagoon in the Coastal Area of Northern East Mediterranean. Bull. Environ. Contam. Toxicol. 2011, 87, 381-385. [CrossRef]

61. Abubakar, A.; Uzairu, A.; Ekwumemgbo, P.A.; Okunola, O.J. Risk Assessment of Heavy Metals in Imported Frozen Fish Scomber scombrus Species Sold in Nigeria: A Case Study in Zaria Metropolis. Adv. Toxicol. 2015, 2015, 303245. [CrossRef]

62. Rubio, C.; Jalilli, A.; Gutiérrez, A.J.; González-Weller, D.; Hernandez, F.; Melon, E.; Burgos, A.; Revert, C.; Hardisson, A. Trace Elements and Metals in Farmed Sea Bass and Gilthead Bream from Tenerife Island, Spain. J. Food Prot. 2011, 74, 1938-1943. [CrossRef]

63. Wojtasik, A.; Woźniak, A.; Stoś, K.; Jarosz, M. Minerals. In Nutrition Standards for the Population of Poland and Their Application; Jarosz, M., Ed.; Narodowy Instytut Zdrowia Publicznego: Warsaw, Poland, 2020; pp. 273-315. (In Polish)

64. Budijono; Hasbi, M. Heavy Metal Contamination in Kotopanjang Dam, Indonesia. IOP Conf. Ser. Earth Environ. Sci. 2021, 695, 012018. [CrossRef]

65. Zapata, F.C.C.; Villanueva, M.C.; Esquivel, R.A.P.; Payano, I.G.U. Bioaccumulation of heavy metals in Oncorhynchus mykiss for export at production centers in the Peruvian Central Highlands. Ambient. Agua 2017, 12, 527-542. [CrossRef]

66. Kalyoncu, L.; Kalyoncu, H.; Arslan, G. Determination of heavy metals and metals levels in five fish species from Iş1klı Dam Lake and Karacaören Dam Lake (Turkey). Environ. Monit. Assess. 2012, 184, 2231-2235. [CrossRef] [PubMed]

67. Sayg1, Y.; Yiğit, S.A. Assessment of Metal Concentrations in Two Cyprinid Fish Species (Leuciscus cephalus and Tinca tinca) Captured from Yeniçağa Lake, Turkey. Bull. Environ. Contam. Toxicol. 2012, 89, 86-90. [CrossRef] [PubMed]

68. Fidan, A.F.; Ciğerci, İ.H.; Konuk, M.; Küçükkurt, I.; Aslan, R.; Dündar, Y. Determination of some heavy metal levels and oxidative status in Carassius carassius L., 1758 from Eber Lake. Environ. Monit. Assess. 2008, 147, 35-41. [CrossRef] [PubMed]

69. Yousif, R.; Choudhary, M.I.; Ahmed, S.; Ahmed, Q. Review: Bioaccumulation of heavy metals in fish and other aquatic organisms from Karachi Coast, Pakistan. Nusant. Biosci. 2021, 13, 73-84. [CrossRef]

70. Makedonski, L.; Peycheva, K.; Stancheva, M. Comparison of heavy metal concentration of some marine fishes from Black and Aegean Seas. Ovidius Univ. Ann. Ser. Chem. 2015, 26, 20-26. [CrossRef]

71. Lounas, R.; Kasmi, H.; Chernai, S.; Amarni, N.; Ghebriout, L.; Hamdi, B. Heavy metal concentrations in wild and farmed gilthead sea bream from southern Mediterranean Sea-Human health risk assessment. Environ. Sci. Pollut. Res. 2021, 28 , 30732-30742. [CrossRef]

72. Kalantzi, I.; Pergantis, S.A.; Black, K.; Shimmield, T.; Papageorgiou, N.; Tsapakis, M.; Karakassis, I. Metals in tissues of seabass and seabream reared in sites with oxic and anoxic substrata and risk assessment for consumers. Food Chem. 2016, 194, 659-670. [CrossRef]

73. Marengo, M.; Durieux, E.D.; Ternengo, S.; Lejeune, P.; Degrange, E.; Pasqualini, V.; Gobert, S. Comparison of elemental composition in two wild and cultured marine fish and potential risks to human health. Ecotoxicol. Environ. Saf. 2018, 158, 204-212. [CrossRef]

74. Łuczyńska, J.; Paszczyk, B.; Łuczyński, M.J. Fish as a bioindicator of heavy metals pollution in aquatic ecosystem of Pluszne Lake, Poland, and risk assessment for consumer's health. Ecotoxicol. Environ. Saf. 2018, 153, 60-67. [CrossRef] 